\title{
PENERAPAN MODEL COOPERATIVE LEARNING TIPE STUDENT \\ TEAMS ACHIEVEMENT DIVISION (STAD) UNTUK MENINGKATKAN HASIL BELAJAR SISWA PADA MATA PELAJARAN IPA
}

\author{
Jubaedah \\ (SD Negeri Cibentar 1 Kec. Jatiwangi Kab. Majalengka)
}

\begin{abstract}
ABSTRAK
IPA adalah salah satu mata pelajaran yang digemari oleh para siswa, namun selama ini hasil belajar mata pelajaran IPA kurang memuaskan. Salah satu faktor yang menyebabkan kemampuan siswa rendah adalah metode mengajar yang selama ini digunakan cenderung membuat siswa pasif dan berpusat pada guru (teacher oriented). Untuk meningkatkan hasil belajar siswa, maka peneliti menerapkan salah model pembelajaran inovatif yaitu model cooperative learning tipe student teams achievement division (STAD) dalam mengajarkan IPA di kelas V SDN Cibentar 1 Kec. Jatiwangi Kab. Majalengka. Penelitian ini merupakan penelitian tindakan kelas (classroom action research), dilaksanakan dalam 3 siklus, setiap siklus terdiri dari 4 tahap : perencanaan, pelaksanakan tindakan, observasi dan refleksi dengan subjek penelitan 30 orang siswa yang terdiri dari 14 orang siswa laki-laki dan 16 orang siswa perempuan. Pada pembelajaran ini guru berperan sebagai fasilitator sedangkan siswa mengkonstruk pengetahuan sendiri melalui kegiatan berkelompok. Hasil penelitian yang dilakukan menunjukkan bahwa ada peningkatan hasil belajar ranah kognitif, psikomotor dan ranah afektif. Hal ini terbukti dari peningkatan nilai rata-rata dan jumlah siswa tuntas pada setiap siklus, yaitu : Nilai rata-rata siklus I sebesar 58,4 dengan 32,2\% siswa tuntas, siklus II sebesar 69,3 dengan 54,4\% siswa tuntas, dan siklus III sebesar 80,3 dengan 85,6\% siswa tuntas. Begitu juga dengan keterampilan ilmiah (keaktifan) dan sikap ilmiah (kerjasama) yang selalu mengalami peningkatan pada setiap siklusnya.
\end{abstract}

Kata kunci : Cooperative learning tipe student teams achievement division (STAD), Hasil belajar, Pembelajaran IPA 


\section{PENDAHULUAN}

Pendidikan adalah salah satu upaya untuk mempersiapkan Sumber Daya Manusia yang berkualitas dan tangguh dalam menghadapi permasalahan yang timbul dalam kehidupan. Dalam UndangUndang No.20 tahun 2003 tentang Sistem Pendidikan disebutkan bahwa Pendidikan nasional berfungsi mengembangkan kemampuan dan membentuk watak serta peradaban bangsa yang bermartabat dalam rangka mencerdaskan kehidupan bangsa, bertujuan untuk berkembangnya potensi agar menjadi manusia yang beriman dan bertakwa kepada Tuhan Yang Maha Esa, berakhlak mulia, sehat, berilmu, cakap, kreatif, mandiri, dan menjadi warga negara yang demokratis serta bertanggung jwab (Depdiknas 2003: 9). Dalam hal ini berarti proses pendidikan berujung pada pembentukan sikap, pengembangan kecerdasan atau intelektual serta pengembangan keterampilan anak sesuai kebutuhan. Ketiga aspek ini (sikap, kecerdasan dan keterampilan) adalah arah dan tujuan pendidikan yang harus diupayakan.

Dalam lingkup sekolah dasar, IPA merupakan salah satu mata pelajaran yang menduduki peranan penting dalam pendidikan. Harapan dalam KTSP untuk mata pelajaran IPA adalah siswa dapat mengembangkan pengetahuan dan pemahaman konsep-konsep IPA yang bermanfaat dan dapat diterapkan dalam kehidupan sehari-hari. Di tingkat Sekolah Dasar diharapkan ada penekanan pembelajaran Salingtemas (Sains, lingkungan, teknologi, dan masyarakat) yang diarahkan pada pengalaman belajar untuk merancang dan membuat suatu karya melalui penerapan konsep IPA dan kompetensi bekerja ilmiah secara bijaksana. Mengacu pada pernyataan sebelumnya hendaknya pembelajaran IPA di SD dapat mengembangkan rasa ingin tahu siswa, selain itu sajian materi IPA juga lebih menekankan pada ruang lingkup yang nyata, sehingga anak mampu menyesuaikan antara pengelaman dengan rasa ingin tahu yang dimilikinya. Selain itu juga IPA menyediakan berbagai pengalaman belajar untuk memahami konsep dan proses IPA. Oleh karena itu, guru perlu menciptakan kondisi pembelajaran IPA yang dapat mendorong siswa untuk aktif dan berpikir induktif dengan cara melakukan investigasi terhadap permasalahan alam di sekitarnya agar diperoleh fakta dan data yang kemudian digeneralisasi agar siswa dapat menguasai konsep IPA dengan baik.

Tetapi faktanya, pembelajaran IPA di Indonesia belum sesuai dengan harapan. Hasil survei Programme for International Student Assessment (PISA) pada tahun 2012 menyatakan bahwa Indonesia menduduki ranking ke-64 dari total 65 negara dalam bidang pengetahuan ilmiah atau sains. Nilai yang diperoleh Indonesia saat itu yaitu 382 untuk bidang sains. Data PISA menunjukkan bahwa siswa di Indonesia kurang mampu dalam memecahkan masalah. Siswa hanya mampu dalam membentuk konsep-konsep, prinsip-prinsip tetapi tidak dapat menghubungkan pengetahuannya ke kehidupan nyata siswa.

Apabila melihat fakta tersebut maka secara umum, permasalahan yang sering kali terjadi dalam dunia pendidikan khususnya di sekolah dasar adalah rendahnya hasil belajar siswa. Menurut Dimyati dan Moedjiono (2006: 200) bahwa "hasil belajar merupakan hasil dari suatu interaksi tindak mengajar atau tindak belajar". Berdasarkan pendapat tersebut dapat disimpulkan bahwa pengertian hasil belajar adalah perbuatan yang tercermin dalam pribadi siswa setelah mengikuti proses pembelajaran. Hasil belajar siswa yang rendah dapat diketahui dengan melihat hasil belajar siswa yang tidak sedikit mendapatkan nilai di bawah kriteria ketuntasan minimal (KKM). Kenyataan ini mengisyaratkan bahwa pengetahuan siswa terhadap kompetensi dasar yang diberikan masih dalam tahap rendah. Berdasarkan hasil observasi peneliti di kelas V SDN Cibentar 1 Kec. Jatiwangi Kab. 
Majalengka pada pembelajaran IPA masih banyak siswa yang mendapatkan nilai dibawah kriteria ketuntasan minimal (KKM). Siswa tidak mampu menjelaskan kembali dan mengaitkan konsep materi yang telah dipelajari. Hal ini mengakibatkan siswa tidak mampu menerapkan materi yang telah dipelajari dalam kehidupan sehari-hari. Keadaan ini memberikan dampak yang sangat besar terhadap prestasi belajar dan hasil belajar siswa dalam mata pelajaran IPA. Berdasarkan hasil ujian akhir semester ganjil tahun 2015-2016 kelas V SDN SDN Cibentar 1 Kec. Jatiwangi Kab. Majalengka pada mata pelajaran IPA, siswa yang mencapai nilai Kriteria Ketuntasan Minimal (KKM) 75, dari jumlah siswa kelas V sebanyak 30 siswa hanya 12 orang siswa atau $40 \%$ siswa yang bisa mencapai KKM sedangkan sisanya sebanyak 18 orang atau $60 \%$ siswa masih berada di bawah nilai KKM. Berdasarkan data tersebut, dapat disimpulkan bahwa siswa kelas V SDN Cibentar 1 Kec. Jatiwangi Kab. Majalengka masih kurang terampil dalam mengolah dan mengaitkan konsep materi yang diajarkan selain itu siswa juga belum terlibat secara aktif baik fisik maupun mental dalam seluruh rangkaian pembelajaran sehingga hasil belajarnya masih tergolong rendah.

Rendahnya hasil belajar yang diperoleh siswa seperti dijelaskan pada masalah di atas perlu mendapat perhatian untuk dilakukan perbaikan dalam proses pembelajarannya. Berpijak dari pendapat di atas, maka dalam merancang kegiatan pembelajaran IPA sebaiknya guru memperhatikan keterlibatan siswa secara aktif baik secara individu maupun kelompok dalam setiap langkah pembelajaran.

Adapun perbaikan dapat dilakukan dengan cara menerapkan pembelajaran yang inovatif dan kreatif. Faktor guru dalam menentukan model pembelajaran yang tepat perlu diperhatikan lebih karena model pembelajaran yang digunakan dapat membantu siswa untuk memahami materi pelajaran. Upaya perubahan itu dengan cara menerapkan model pembelajaran yang dianggap tepat, salah satu model yang dianggap tepat adalah model pembelajaran kooperatif. Model cooperative learning dikembangkang untuk mencapai beberapa tujuan diantaranya yaitu ketercapaian prestasi akademis, toleransi dan penerimaan terhadap keanekaragaman, dan mengembangkan Keterampilan social. Lingkungan belajar untuk cooperative learning ditandai oleh proses yang demiokratis dan peran aktif siswa dalam memutuskan segala yang harus dipelajari dan bagaimana caranya. Dalam penelitian ini model cooperative learning yang akan diterapkan sebagai upaya perbaikan adalah tipe student teams achievement division (STAD), dimana guru menyajikan informasi akademis melalui kegiatan kelompok. Anggota tim menggunakan worksheet untuk menguasai berbagai materi dan kemudian saling membantu untuk mempelajari berbagai materi melalui kegiatan tutoring, saling memberikan kuis, dan diskusi tim.

Berdasarkan latar belakang masalah, maka yang menjadi tujuan dalam penelitian ini adalah untuk memperoleh gambaran apakah Penerapan Pendekatan Konstruktivisme model cooperative learning tipe student teams achievement division (STAD) pada Pembelajaran IPA dapat meningkatkan hasil belajar siswa di kelas V SDN Cibentar $1 \mathrm{Kec}$. Jatiwangi Kab. Majalengka.

\section{LANDASAN TEORI}

Tujuan pembelajaran IPA di SD yaitu menumbuhkan minat siswa akan pembelajaran IPA, sehingga dengan belajar IPA siswa merasa senang dan mampu menguasai konsep-konsep IPA yang dapat diterapkan dalam kehidupan sehari-hari. Untuk itu siswa harus sering berlatih terutama pengembangan katerampilan dan pengembangan konsep dalam suatu penemuan baru. Hal ini bertujuan agar siswa mampu memecahkan permasalahanpermasalahan yang berkaitan dengan IPA. Dengan mengkaji IPA, selain menambah 
pengetahuan dan melihat fenomena-fenomena yang terjadi di alam, diharapkan dapat menambah kecintaan terhadap alam serta keyakinan dan keimanan siswa akan adanya kebesaran Tuhan Yang Maha Esa.

1. Hasil Belajar

Belajar adalah usaha yang dilakukan oleh seseorang untuk meningkatkan kompetensi kemampuannya dari yang belum tau menjadi tau dan dari yang belum bisa menjadi bisa. Hasil belajar merupakan bagian terpenting dalam pembelajaran. (Sudjana, 2009: 3) mendefinisikan hasil belajar siswa pada hakikatnya adalah perubahan tingkah laku sebagai hasil belajar dalam pengertian yang lebih luas mencakup bidang kognitif, afektif, danpsikomotorik. Nawawi (Susanto, 2013:5) mengemukakan 'hasil belajar dapat diartikan sebagai tingkat keberhasilan siswa dalam mempelajari materi pelajaran di sekolah yang dinyatakan dalam skor yang diperoleh dari hasil tes mengenal sejumlah materi pelajaran tertentu'. Berdasarkan pandangan tersebut dapat disimpulkan bahwa hasil belajar merupakan perubahan atau kemampuan yang dimiliki seseorang (siswa) setelah mengikuti proses belajar dan dapat diukur dengan skor melalui tes. Berdasarkan hal tersebut, tes dapat menggambarkan keberhasilan siswa dalam pembelajaran.

Siswa dikatakan berhasil dalam belajar apabila telah mencapai tujuan pembelajaran yang sudah ditentukan. Sebaliknya, siswa dikatakan belum berhasil dalam belajar apabila belum mencapai tujuan pembelajaran yang sudah ditentukan. Hasil belajar seseorang dipengaruhi oleh 2 (dua) factor yaitu factor internal dan eksternal. Faktor internal adalah faktor dari dalam individu baik fisik

(jasmaniah) maupun psikis. Aspek jasmaniah mencakup kondisi dan kesehatan jasmani dari individu sedangkan aspek psikis menyangkut kondisi kesehatan psikis, kemampuan-kemampuan intelektual, motivasi, konsentrasi, minat, fantasi, sifat kreatif, pemahaman, dan lain-lain. Adapun faktor eksternal adalah faktor di luar diri siswa baik faktor fisik maupun sosial psikologis yang berada pada lingkungan keluarga, sekolah dan masyarakat.

Menurut Bloom (Sudjana, 2009:22) membagi hasil dari belajar menjadi tiga bagian, yakni ranah kognitif, ranah afektif, dan ranah psikomotor. Ranah kognitif berkaitan dengan hasil belajar siswa yakni tingkatan intelektual siswa. Ranah afektif bekenaan dengan sikap siswa. Sedangkan ranah psikomotor berkaitan dengan hasil belajar siswa yang berupa keterampilan atau kemampuan secara fisik yang dilakukan atau dimiliki oleh siswa.

Dari pemaparan beberapa ranah yang bisa menentukan keberhasilan belajar, dalam penelitian ini difokuskan pada pencapaian hasil belajar dalam ranah kognitif yang berkaitan dengan tingkatan intelektual atau pemahaman siswa setelah mengikuti proses pembelajaran. Adapun tingkatan ranah kognitif yang diukur ialah rentang $\mathrm{C} 1$ (mengingat) hingga $\mathrm{C} 3$ (Menerapkan) yakni indikator menyebutkan, menunjukan, dan menentukan. Ranah afektif pada rentang A1 (Menerima) hingga A2 (Merespon) yakni pada indikator mematuhi dan memilih. Sementara pada ranah psikomotor rentang P1 (Meniru) hingga P3 (Presisi), yakni indikator mematuhi, melaksanakan, dan menunjukan.

2. Model cooperative learning tipe student teams achievement division (STAD)

Model kooperatif adalah suatu model pembelajaran dimana siswa belajar dalam kelompok-kelompok kecil secara kolaboratif yang anggotanya empat sampai enam orang, dengan struktur kelompok heterogen yang bekerja sama untuk menyelesaikan permasalahan atau mencapai tujuan bersama. Hal tersebut senada dengan pernyataan Sanjaya, (2008: 239) "Model pembelajaran kelompok adalah rangkaian kegiatan belajar yang dilakukan oleh siswa dalam kelompok-kelompok tertentu untuk mencapai tujuan pembelajaran yang telah dirumuskan”. Dengan adanya kerjasama ini 
menuntut siswa aktif, memberi kepercayaan kepada siswa untuk bersama-sama bekerja dalam menyelesaikan suatu permasalahan, atau tugas yang diberikan oleh guru. Arends (2008: 4) "Model Cooperative Learning menuntut kerjasama dan interdependensi siswa dalam struktur tugas, struktur tujuan, dan struktur reward".

Terdapat beberapa karakteristik dari pembelajaran cooperative learning diantaranya yaitu saling ketergantungan positif, tanggung jawab perorangan, tatap muka, komunikasi antar anggota, dan evaluasi proses kelompok. Teori yang melandasi pembelajaran Cooperative adalah teori kontruktivisme. Pada dasarnya teori kontruktivisme dalam belajar adalah suatu pendekatan dimana siswa harus secara individual menemukan dan menstransformasikan informasi yang kompleks, memeriksa aturan yang ada dan merevisinya bila perlu". dalam hal ini siswa dituntut aktif serta dapat memecahakan suatu permasalahan.

Terdapat banyak tipe pembelajaran cooperative learning salah satunya adalah tipe student teams achievement division (STAD) Menurut Lestari (2013: 2) bahwa : "STAD merupakan salah satu motode pembelajaran Kooperatif yang paling sederhana, karena model pembelajaran ini dapat digunakanan untuk menstimulasi siswa agar dapat terlibat secara aktif dan saling memberikan dukungan satu sama lain dalam kelompok untuk menuntaskan materi yang dipelajari".

Inti dari Cooperative Learning tipe STAD adalah guru menyampaikan suatu materi, kemudian para siswa bergabung dalam kelompoknya yang terdiri atas 4-5 orang untuk menyelesaikan soal-soal yang diberikan oleh guru setelah selesai mereka menyerahkan pekerjaanya secara tunggal untuk setiap kelompok kepada guru. Model pembelajaran STAD, memungkinkan guru dapat memberikan perhatian terhadap siswa, baik itu hubungan guru dengan siswa, siswa dengan siswa. Adakalanya belajar dengan teman sendiri lebih mudah dan cepat dipahami ketimbang belajar dengan gurunya, dalam hal ini model pembelajaran kooperatif tipe STAD mengacu kepada model pembelajaran kelompok. Menurut Rusman (2014: 215) Langkah-langkah pembelajaran Cooperative Learning tipe STAD adalah sebagai berikut:

a. Penyampaian Tujuan dan Motivasi

b. Pembagian kelompok

c. Presentasi dari Guru

d. Kegiatan Belajar dalam Tim (Kerja Tim)

e. Kuis (Evaluasi)

f. Penghargaan Prestasi Tim

Mengarah pada langkah-langkah pembelajaran seperti penjelasan sebelumnya bahwa model pembelajaran STAD lebih menekankan pada pendekatan student center, dimana siswa dituntut aktif berdiskusi, bertanya dan menyampaikan pendapat. Peran guru hanya sebatas fasilitator, memberikan bimbingan dan arahan mengenai hal-hal yang belum siswa ketahui. Dengan menerapkan model pembelajaran STAD, dapat meningkatkan semangat belajar siswa yang berdampak pada penigkatan hasil belajar. Model kooperatif tipe STAD kaitannya dengan pembelajaran IPA menurut Fitriani (2015: 18) "Cooperative Learning, dapat dijadikan sebagai model pembelajaran yang efektif terlebih dengan penerapan metode yang dikombinasikan dengan tepat.

\section{METODOLOGI}

Metode yang digunakan dalam penelitian ini yaitu metode penelitian tindakan kelas (Class Room Action). Model penelitian tindakan kelas (PTK) yang digunakan dalam penelitian ini adalah model penelitian tindakan kelas berdasarkan teori John Elliot. Model ini pada setiap siklusnya terdiri terdiri dari beberapa aksi, yaitu antara tiga sampai lima aksi (tindakan). Sementara itu, setiap tindakan terdiri dari beberapa langkah yang terealisasi dalam bentuk kegiatan belajarmengajar. Pengertian siklus pada kesempatan ini adalah satu putaran kegiatan yang terdiri dari perencanaan (planning), tindakan (action), observasi (observation) 
dan refleksi (reflection). Pada penelitian ini, rancangan awal akan dilakukan tiga siklus, tetapi apabila hasil refleksi menghendaki tindakan lanjutan maka akan dilakukan perbaikan pada siklus selanjutnya sampai tujuan penelitian tercapai.

Metode pengumpulan data pada penelitian ini dilakukan dengan observasi proses belajar mengajar dan tes. Data yang terkumpul dianalisis dengan menggunakan analisis kuantitatif dan analisis kualitatif. Untuk analisis secara kuantitatif digunakan analisis deskriptif yaitu skor rata-rata dan persentase. Data yang dianalisa berupa ratarata dan persentase hasil belajar siswa. Teknik analisis data ini digunakan untuk mengetahui apakah terjadi peningkatan hasil belajar siswa dengan penerapan model cooperative learning tipe student teams achievement division (STAD) dalam pembelajaran IPA.

\section{HASIL DAN PEMBAHASAN}

Hasil pembelajaran IPA dengan menggunakan model cooperative learning tipe student teams achievement division (STAD) di kelas $\mathrm{V}$ diperoleh data hasil belajar sebagai berikut:

\section{Siklus 1}

Penelitian Siklus 1 dilaksanakan pada hari Senin, 12, 13, dan 15 Maret 2016 di kelas V SDN Cibentar Kec. Jatiwangi Kab. Majalengka dengan siswa berjumlah 30 orang. Langkah pembelajaran dilaksanakan sesuai dengan tahapan model cooperative learning tipe student teams achievement division (STAD). Dalam pelaksanaannya, peneliti dibantu oleh dua orang observer.

Berdasarkan hasil observasi temuan yang didapat pada pelaksanaan pembelajaran siklus 1 diantaranya yaitu : Berdasarkan pada data serta temuan yang penulis dapatkan di lapangan pada siklus 1 Siswa belum berani mengajukan pertanyaan mengenai materi yang belum dipahaminya, siswa kurang memperhatikan penjelasan guru, siswa kurang berani menjawab pertanyaan mengenai materi secara individu, ini disebabkan karena siswa kurang memiliki percaya diri dan sudah terbiasa untuk menjawab pertanyaan secara klasikal. Kondisi tersebut menyebabkan pembelajaran kurang berjalan secara optimal karena kurang terjadinya interaksi dua arah. Selain itu terdapat beberapa siswa yang tidak mengikuti diskusi dengan baik, masih ada beberapa siswa yang mengobrol dengan temanya, guru belum maksimal dalam mengkondisikan siswa di dalam melaksanakan diskusi kelompok, terdapat beberapa siswa yang masih pasif, selanjutnya siswa kurang mampu bekerja sama dengan kelompoknya meskipun pembelajaran dilaksanakan dengan menggunakan model cooperative learning tipe student teams achievement division (STAD), dan masih terdapat siswa yang tidak ikut terlibat dalam kegiatan menyimpulkan materi pada akhir pembelajaran. Hasil evaluasi terhadap hasil belajar pada siklus I diperoleh data yang menggambarkan adanya peningkatan, terlihat dari rata-rata nilai dan persentase siswa tuntas yang lebih baik dibandingkan hasil penilaian awal sebelum tindakan. Sebelum tindakan siswa tuntas hanya $40 \%$ dari 30 orang siswa dan setelah dilakukan tindakan pada siklus 1 meningkat menjadi $58,8 \%$ siswa tuntas. Walaupun demikian peningkatan yang terjadi belum sesuai dengan target penelitian sehingga penelitian dilanjutkan pada siklus 2 dengan mempertimbangkan berbagai hal yang menjadi kelemahan pada siklus 1. Maka, berdasarkan hasil refleksi pada siklus 1, dalam pelaksanaan siklus 2, guru (peneliti) melakukan perbaikan diantaranya guru harus mampu memotivasi siswa untuk bertanya agar materi dapat dipahami dengan baik. Maka dari itu, rencana perbaikan yang peneliti akan lakukan adalah pada saat kegiatan apersepsi yaitu dibuat lebih menarik lagi dan dengan menampilkan media gambar. Dengan adanya media gambar diharapkan dapat memancing siswa untuk lebih antusias dan termotivasi dalam mengikuti pembelajaran. 
Perbaikan lainnya juga dilakukan diantaranya dengan meninggikan intonasi suara saat pembelajaran sehingga dapat mengkondisikan seluruh siswa di dalam kelas. Peneliti juga berupaya untuk lebih menghidupkan suasana interaksi dengan siswa melalui berbagai penghargaan, penguatan, dan pembiasaan agar siswa berani dan percaya diri untuk melakukan interaksi baik dengan guru saat proses pembelajaran ataupun dengan siswa lainnya saat diskusi kelompok. Selanjutnya upaya peneliti untuk mengatasi diskusi kelompok yang kurang kondusif adalah dengan pengaturan kelompok yang lebih baik, seperti memisahkan siswa yang menjadi sumber kegaduhan dan menyeimbangkan keadaan kelompok menurut tingkat kecerdasannya, seperti mengelompokan siswa yang memiliki tingkat kecerdasan tinggi, sedang, dan kurang.

\section{Siklus 2}

Penelitian Siklus 2 dilaksanakan pada hari Senin, 19, 21, dan 23 Maret 2016 di kelas V SDN Cibentar Kec. Jatiwangi Kab. Majalengka dengan siswa berjumlah 30 orang. Langkah pembelajaran dilaksanakan sesuai dengan tahapan model cooperative learning tipe student teams achievement division (STAD). Dalam pelaksanaannya, peneliti dibantu oleh dua orang observer.

Adapun temuan pada siklus 2 diantaranya yaitu: aktivitas siswa dan guru sudah mengalami peningkatan jika dibandingkan pada proses pembelajaran siklus sebelumnya. Guru sudah cukup baik dalam melaksanakan aktivitas diskusi dengan baik, namun ada beberapa hal yang masih kurang terutama pada kegiatan memonitoring siswa dalam kegiatan diskusi, dengan demikian perlu ditingkatkan. Keterampilan siswa pada saat bertanya jawab sudah cukup baik, kemudian siswa memperhatikan penjelasan materi dari guru dan siswa melaksanakan tes diakhir tindakan dengan baik. Hanya pada saat diskusi masih perlu bimbingan sehingga kegiatan diskusi dapat berjalan lebih efektif. Selanjutnya masih ada sebagian siswa yang melaksanakan aktivitas diluar pembelajaran terutama mengobrol dengan siswa yang lainnya, selain itu ada satu kelompok yang saling tunjuk ketika diminta menyampaikan pendapatnya dalam kegiatan diskusi dan presentasi di depan kelas. Pada siklus 2 ini, hasil belajar siswa masih kurang maksimal ditandai dengan skor rata-rata yang kurang jika dibandingkan dengan nilai KKM, skor rata-ratanya adalah 69.3 dengan ketuntasan belajar secara klasikal $54.4 \%$ dari jumlah keseluruhan siswa. Dengan demikian maka pembelajaran dilanjutkan pada siklus berikutnya dengan memperhatikan berbagai temuan yang ada sehingga pelaksanaan siklus 2 dapat berjalan dengan lebih efektif. Adapun perbaikan proses pembelajaran difokuskan pada pembimbingan dan pengelolaan kegitan kelompok serta pemberian motivasi pada siswa selama mengikuti proses pembelajaran.

3. Siklus 3

Penelitian Siklus 3 dilaksanakan pada hari Senin, 4, 7, dan 8 April 2016 di kelas V SDN Cibentar Kec. Jatiwangi Kab. Majalengka dengan siswa berjumlah 30 orang. Langkah pembelajaran dilaksanakan sesuai dengan tahapan model cooperative learning tipe student teams achievement division (STAD). Dalam pelaksanaannya, peneliti dibantu oleh dua orang observer. Adapun temuan pada siklus 2 diantaranya yaitu:

guru mengalami peningkatan dan hampir sempurna, terlihat bahwa guru sudah melaksanakan kegiatan awal dengan baik. Mulai dari mengucapkan salam, kemudian mengkondisikan siswa sebelum pembelajaran, menyampaikan apersepsi dengan baik dan guru menyampaikan tujuan pembelajaran. Pada siklus 3 siswa sudah terbiasa dengan tanya jawab, siswa saling menanggapi hasil dari pekerjannya masing-masing, terlihat adanya peningkatan proses tanya jawab yang dilakukan oleh siswa dengan siswa yang lainnya, proses ini dimungkinkan karena siswa sudah terbiasa dengan menggunakan model pembelajaran 
yang dilaksanakan oleh guru. Hasil belajar siswa sudah baik ditandai dengan skor ratarata yang sudah di atas KKM yang ditentukan, yaitu 80.3 dengan ketuntasan belajar secara klasikal adalah $85.6 \%$ ini menunjukan peningkatan yang signifikan dibandingkan siklus-siklus sebelumnya. Dengan data hasil belajar tersebut target penelitian tercapai, sehingga penelitian berhenti pada siklus 3 .

Dengan berakhirnya penelitian pada siklus 3 dengan hasil sebagaimana dikemukakan di atas, terbukti bahwa penerapan model cooperative learning tipe student teams achievement division (STAD) dalam pembelajaran IPA dapat meningkatkan hasil belajar siswa kelas $\mathrm{V}$ SDN Cibentar 1 Kec. Jatiwangi Kab. Majalengka. Secara lebih rinci peningkatan hasil belajar siswa kelas V SDN Cibentar 1 Kec. Jatiwangi Kab. Majalengka, dapat dilihat pada tabel di bawah ini.

Rekapitulasi hasil belajar ranah kognitif siswa pada setiap siklus didapat data sebagai berikut:

Table 1.

Rekapitulasi Peningkatan Hasil belajar kognitif

\begin{tabular}{|l|c|c|c|}
\hline \multicolumn{1}{|c|}{ Pencapaian } & $\begin{array}{c}\text { Data } \\
\text { siklus } \\
1\end{array}$ & $\begin{array}{c}\text { Data } \\
\text { siklus } \\
2\end{array}$ & $\begin{array}{c}\text { Data } \\
\text { siklus } \\
3\end{array}$ \\
\hline Rata-rata & 58,4 & 69,3 & 80,3 \\
\hline Jumlah siswa tuntas (\%) & 32,2 & 54,4 & 85,6 \\
\hline Jumlah siswa tidak tuntas (\%) & 67,8 & 45,4 & 14,4 \\
\hline
\end{tabular}

Dari Tabel 1., tersebut terlihat bahwa baik nilai rata-rata maupun persentase jumlah siswa yang tuntas mengalami peningkatan pada tiap siklusnya. Dari data tersebut diketahui bahwa pembelajaran IPA dengan menerapkan cooperative learning tipe student teams achievement division (STAD) terbukti dapat meningkatkan hasil belajar pada ranah kognitif siswa.

Dari data yang tertera pada tabel di atas, diketahui bahwa perkembangan persentase kriteria ketuntasan minimal mengalami peningkatan, dari siklus I ke siklus II mengalami peningkatan sebesar $22,2 \%$ sedangkan dari siklus II ke siklus III naik $31,2 \%$. Selain pada ranah kognitif peningkatan juga terjadi pada aspek psikomtor, dengan hasil sebagai berikut:

Table 2.

Rekapitulasi hasil belajar ranah psikomotor

\begin{tabular}{|c|c|c|c|c|}
\hline \multirow{2}{*}{ Siklus } & \multicolumn{4}{|c|}{ Kriteria } \\
\cline { 2 - 5 } & SB & B & C & K \\
\hline 1 & 1 & 4 & 16 & 9 \\
\hline 2 & 8 & 14 & 7 & 1 \\
\hline 3 & 18 & 11 & 1 & 0 \\
\hline
\end{tabular}

Sesuai dengan data pada tabel 2., terlihat bahwa hasil belajar siswa pada ranah psikomotor mengalami peningkatan pada setiap siklusnya. Hal tersebut dapat ditunjukan dengan terjadi peningkatan jumlah siswa dengan kategori baik dan sangat baik pada setiap siklusnya.

Selain ranah kognitif dan psikomotor, hasil belajar siswa pada ranah afektif juga mengalami peningkatan. Hal ini ditunjukan dengan peningkatan jumlah siswa yang mendapat kategori baik dan sangat baik untuk ranah afektif pada aspek kerjasama dan menghargai pendapat orang lain. Secara lengkap data peningkatan hasil belajar siswa pada ranah afektif dapat dilihat pada tabel berikut.

Table 3.

Rekapitulasi hasil belajar ranah psikomotor

\begin{tabular}{|c|c|c|c|c|}
\hline \multirow{2}{*}{ Siklus } & \multicolumn{4}{|c|}{ Kriteria } \\
\cline { 2 - 5 } & SB & B & C & K \\
\hline 1 & 1 & 8 & 15 & 6 \\
\hline 2 & 10 & 15 & 5 & 0 \\
\hline 3 & 21 & 9 & 0 & 0 \\
\hline
\end{tabular}

Peningkatan hasil belajar siswa baik pada ranah kognitif, afektif, maupun 
psikomotor dikarenakan model pembelajaran cooperative learning tipe student teams achievement division (STAD) merupakan salah satu model yang menghendaki siswa untuk ikut berperan aktif dalam mengikuti kegiatan pembelajaran khususnya melalui kegitan kelompok, dengan ikut berperan aktifnya siswa dalam kegiatan pembelajaran akan lebih memudahkan siswa dalam memahami materi pelajaran yang sedang dipelajarinya. Hal tersebut senada dengan pernyataan Sanjaya, (2008: 239) "Model pembelajaran kelompok adalah rangkaian kegiatan belajar yang dilakukan oleh siswa dalam kelompok-kelompok tertentu untuk mencapai tujuan pembelajaran yang telah dirumuskan". Dengan adanya kerjasama ini menuntut siswa aktif, memberi kepercayaan kepada siswa untuk bersamasama bekerja dalam menyelesaikan suatu permasalahan, atau tugas yang diberikan oleh guru. Selain itu proses pembelajaran akan menjadi lebih menarik, sebab peserta didik tidak hanya mendengarkan tetapi juga mengamati peristiwa yang terjadi melalui kegitan bertukar ide dan gagasan. Melalui pembelajaran kooperatif siswa diarahkan untuk ikut aktif dalam berbagai kegiatan seperti berdiskusi dan presentasi. Seiring dengan meningkatkatnya aktifitas siswa dalam proses pembelajaran ranah sikap pun ikut meningkat dikarenakan pada setiap aktifitas pembelajaran adanya proses pembiasaan penanaman sikap dan karakter yang baik. Pelaksanaan pembelajaran dengan model STAD siswa bukan hanya sekedar mendapat informasi dari guru melainkan adanya keterlibatan siswa secara langsung. Shoimin, (2014: 61) mengemukakan "Proses pembelajaran bukan lagi sekedar transfer pengetahuan dari guru ke siswa, melainkan proses pemerolehan konsep yang berorientasi pada keterlibatan siswa aktif". Dengan demikian pembelajaran yang berhasil dapat diketahui dari proses yang dilakukan sebanding dengan hasil yang diperoleh siswa. Artinya pembelajaran dengan melibatkan aktivitas siswa akan berdampak pada hasil belajar siswa yang meningkat.

Selain peningkatan aktifitas siswa factor lain yang juga berpengaruh pada ketercapaian hasil belajar yaitu kondusifnya sarana penunjang kegiatan belajar mengajar di kelas sejalan dengan itu, Wiyani (2013: 9) mengemukakan bahwa: "Jika kondisi kelas berantakan, semrawut tanpa penataan yang baik serta berbagai sarana yang dimilikinya kurang memadai sudah tentu akan menghambat kegiatan belajar mengajar. Sebaliknya, jika kelas dikelola dengan baik, sangat dimungkinkan keberhasilan kegiatan belajar mengajar akan tercapai. Berdasarkan pendapat tersebut, ini menunjukan bahwa betapa pentingnya kondisi kelas yang baik dan menciptakan suasana kelas yang kondusif karena hal ini dapat mempengaruhi terhadap hasil belajar siswa.

\section{SIMPULAN DAN SARAN}

\section{A. Simpulan}

1. Pembelajaran model pembelajaran cooperative learning tipe student teams achievement division (STAD) sangat relevan untuk diterapkan dalam pembelajaran IPA. Melalui model STAD, siswa dapat menemukan penyelesaian dari suatu materi secara kolaboratif dengan teman kelompok. Model pembelajaran STAD membuat pembelajaran IPA lebih bermakna dan menyenangkan bagi siswa.

2. Penerapan model pembelajaran cooperative learning tipe student teams achievement division (STAD) dapat meningkatkan hasil belajar siswa baik pada aspek kognitif, afektif, maupun psikomotor. Hal ini terbukti dari peningkatan nilai rata-rata dan persentase siswa tuntas pada setiap siklusnya yang diikuti juga peningkatan jumlah siswa dengan kategori baik dan sangat baik untuk aspek psikomotor dan afektif. 


\section{B. Saran}

1. Guru harus memperhatikan pengelolaan kelas selama kegiatan kelompok berlangsung terutama tata letak tempat duduk siswa agar kegiatan pembelajaran dapat berlangsung secara efektif.

2. Guru harus memperhatikan waktu dan penentuan anggota kelompok hal ini dikarenakan siswa membutuhkan waktu yang lebih lama ketika berdiskusi jika siswa sulit bekerja sama dengan anggota kelompoknya.

3. Meskipun dengan penerapan pembelajaran STAD dapat meningkatkan hasil belajar siswa pada pembelajaran IPA, perlu adanya penelitian lebih lanjut pada materi dan subjek yang berbeda di tingkat sekolah dasar sebagai upaya untuk mengembangkan kompetensi sains siswa yang lainnya.

\section{DAFTAR PUSTAKA}

Aunurrahman. (2013). Belajar dan Pembelajaran. Bandung: Alfabeta

BSNP. (2006). Standar Kompetensi dan Kompetensi Dasar Sekolah Dasar/Madrasah Ibtidaiyah (Lampiran 1 Peraturan Mendiknas No. 22 Tahun 2006). Jakarta: Depdiknas. Dirjen Mandikdasmen. Direktorat Pembinaan TK dan SD.

Cahyo, Agus. (2013). Panduan Aplikasi Teori-Teori Belajar Mengajar Teraktual dan Terpopuler. Yogyakarta: Diva Press.

Dahar, Wilis Ratna. (2006). Teori-teori Belajar dan Pembelajaran. Jakarta: Erlangga.

Depdiknas. (2003). Undang-Undang Nomor 20 Tahun 2003 Tentang Sistem
Pendidikan Nasioanl. Jakarta: Depdiknas.

Dimyatidan Mudjiono. (2006). Belajar dan

Pembelajaran. Jakarta:

RinekaCipta

Joyce, Bruce, dkk (2011). Models Of

Teaching. Yogyakarta: Pustaka Pelajar.

Mulyasa, E. (2005). Implementasi Kurikulum 2004 Panduan

Pembelajaran KBK. Bandung: Rosdakarya

Rustaman, N. (2007). Assesmen dalam Pembelajaran Sains. Bandung: Program doktor pendidikan IPA sekolah pasca sarjana UPI.

Sagala, Syaiful. (2013). Konsep dan Makna Pembelajaran. Bandung: Alfabeta.

Sanjaya, W. (2008). Strategi Pembelajaran Berorientasi Standar Proses

Pendidikan. Jakarta : Kencana Prenada Media Group.

Sanjaya, Wina. (2012). Strategi Pembelajaran Berorientasi Standar Proses Pendidikan. Jakarta: Kencana Prenada Media Group.

Sugihartono, dkk. (2007). Psikologi Pendidikan. Yogyakarta: UNY Press.

Trianto. (2014). Model Pembelajaran Terpadu. Jakarta: PT Bumi Aksara.

Trianto. (2010). Model Pembelajaran Terpadu. Jakarta: PT Bumi Aksara.

Usman, Uzer M. (2008). Menjadi Guru Profesional. Bandung: Remaja Rosdakarya.

Widodo, dkk. (2007). Pendidikan IPA SD. Bandung: UPI PRESS.

Wiriaatmadja. Rochiati. (2009). Metode Penelitian Tindakan Kelas. Bandung: PT Remaja Rosdakarya. 